\section{Should Engineers Join a Union?}

\author{
R. W. SORENSEN \\ FELLOW AIEE
}

\begin{abstract}
Pointing out that engineers should have the right to join unions or not as their own consciences dictate, this author believes that by doing so they are likely to impair their claims to professional status, and suggests that they are competent to find other ways of correcting unfair situations.
\end{abstract}

$\mathrm{E}$ NGINEERS attain professional status in a unique way. Lawyers and physicians, upon the completion of the prescribed formal educational requirements of their respective professions, are immediately inducted into the profession by the opening of an office for practice or by joining forces with others of the profession in an established office. Engineers, upon the completion of formal educational programs (usually the work prescribed for a baccalaureate degree), get jobs as general roustabouts doing things which more often than not give no immediate evidence of a need for higher mathematics, modern physics, advanced engineering knowledge, or ability to apply engineering technique. Even at best, novitiate engineers cannot expect closer acquaintance with the real engineering problems they long to solve than that obtained by observing how engineers direct the things they are doing, or that which may be incident to training courses involving the simpler phases of manufacture and operation together with some class instruction. The latter is more often preparation for future engineering work than a study of the tasks performed in the daily training-course routine.

However humble the first jobs for graduates of engineering colleges may be, those performing the duties incident thereto soon demonstrate their qualifications or lack of qualifications for success in the practice of engineering as a profession. The reasons why this is so are clearly declared by the following statement of Gano Dunn, "It is not what the engineer does, but how he does it! Not what the engineer's occupation is, but the intellectual processes by which he attacks that occupation." In other words, the engineers employed in industry do not occupy horizontal levels in the industrial scale of achievement and responsibility, but are found scattered throughout all its many departments.

Engineers in a number of occupations and localities have recently been subject to considerable pressure to unionize. This pressure has been very largely from outside organizations, rather than from the engineers themselves. Indeed such minor urge for unionization as has come from the engineers seems to be limited to those members of the great fraternity of engineering graduates who have never really become engineers, because of inability to keep up with the advancements and demands of the profession; or who have been so unfortunate as to obtain employment with firms having the shortsighted policy of getting from their technical staffs all the service possible by paying a minimum wage rather than a just compensation for the work done. This error is rare, because fortunately few industrial firms tolerate for long executives who by such practice show little knowledge of the type of management essential

R. W. SORENSEN is head of the department of electrical engineering, California Institute of Technology, Pasadena, and official nominee for AIEE president. to continued business success. Indeed the movement to unionize engineers, set up a few months ago, at present seems to be at a very low ebb. In my opinion, this is due to the prevalence of good management, and a corresponding failure on the part of able engineers to see any reason for an engineers' union. Though the crest of the demand has subsided, aware of the fact that when there is smoke there is some fire, and urged by requests from the AIEE and the American Society of Mechanical Engineers committees on the economic status of the engineer, I am constrained to say to our younger engineers: "Look well before you leap-engineers who join unions may be committing the act which for all time classifies them as craftsmen and forever bars them from attaining the status of professional engineers."

Reasons why this is true should be quite clear to persons who analyze questions in an engineering way. James $\mathrm{H}$. Herron, in a paper entitled "Unionization of Engineers" 2 says, among other things:

"The most important union which has grown up in engineering types of employment is the Federation of Architects, Engineers, Chemists, and Technicians, affiliated with the CIO. The aims and viewpoints of this organization appear to be quite in accord with familiar laborunion purposes and ideals. According to a report of an annual meeting of the Federation which appeared in the Architectural Forum for November 1933, the Federation supported the following program:

"1. Thirty hours of work per week.

"2. Only 'extreme emergency' overtime, to be paid for at doubletime rate."

Any code which prescribes such limitations is obviously designed to guard against exploitation of craftsmen and regardless of the success attained for that purpose is quite out of place for professional men doing mental rather than physical work. Such work cannot be handed on to others at shift-changing time or in many cases even be deferred until another day. Engineers, therefore, who develop habits of thinking in connection with their work as prescribed by the union code would be in grave danger of self-disqualification as professional men.

History proclaims the truth of the ancient saying: "For as a man thinketh, so is he." Men whose thoughts are directed to such objectives as a minimum of work for a maximum of pay cannot expect to experience the joy of finding an interest in their work which transcends all other interests. Without that supreme interest in a profession which makes men forget everything but the problems to be solved, and causes them to work to the limits of health and endurance forgetting time and even many of the social demands of their fellow men, there can be little probability of professional success. Professional success means that when men have finished their active years of engineering practice, they can take a backward look and say: "Those are our additions to the knowledge and the practice of our 
profession; because of what we have done men will live better than would be the case had those things been left undone."

Engineers are professional men aiming at high standards and striving to attain the same degree of recognition as that accorded the legal and medical professions. In case of severe illness, how much confidence would a patient have in a physician who after a few conferences said to him: "You will have to wait until next week for attention; I have worked all the hours I am allowed this week and can give your case no further thought at this time; or, if I do, I'll have to double my usual charge"? Perhaps the patient would need no further attention if very ill. How often would persons in need of legal aid and advice employ an attorney who said to his clients: "My allotted weekly number of work hours has been used. This is indeed unfortunate, because I have just thought of a line of argument which would be very favorable to your case if it could be studied and used for next Monday's trial, but nothing can be done about it; we must do what we can with the preparation that has been made"?

All professions include two types of work; namely, work of a research type which tends toward new developments that will enable the profession to keep pace with its rapidly and constantly changing problems; and work which can be done only by technical specialists, but is so repetitious that for the professional practitioner it becomes largely routine. The physician does his routine work in the daily treatment of his patients' minor ills; the lawyer in his preparation of the many simple agreements that are a part of the normal activities of his clients; and the engineer in his everyday tasks of building and operating standard apparatus and equipment.

No definite portion of a man's actual years in a profession which should be devoted to the training work of drafting, operating, etc., can be prescribed, but it is obvious that some stay at it overly long and become permanently subprofessional rather than professional engineers. If many have to do this simply because they are the forgotten men of the profession, such men, of course, will become discouraged and, if there seems no other way out, will think of unionization as a way to obtain coveted professional standing and increased pay.

The responsibility for this onerous situation may belong to unwise management; or to the failure of engineers to qualify properly for work more complex than their current occupations; or to a combination of unwise management and lack of forethought on the part of engineers in anticipating the requirements of the larger responsibilities that come with desired promotion.

Engineers must do their part by keeping well qualified for advancement, and management must do its part by avoiding tendencies to have advancement opportunities become departmental and by keeping working conditions and salaries for engineers at levels equitable in comparison with the work done and wages obtained by craftsmen by union methods. The question of wage is hardly pertinent to this article, but quite often one encounters, particularly in operating organizations, a deficiency in promotional programs that makes free transfer from department to depart- ment very difficult or even impossible. This situation seems to be more acute where promotion is obtained by examination (as in civil service) than it is where examinations are not used, although not all organizations using the latter scheme are free from this fault. In some instances, men have found it necessary to resign from a company and be reemployed for another department to get the consideration desired.

The question as to whether engineers shall or shall not become members of a union must be considered entirely as a personal matter for each individual, who as such has the free right to choose what seems to be the better way. This does not mean that the engineering societies have no responsibility in advising young engineers, who are the ones most affected by the decision regarding the question of unionization, but it does mean that the responsibility of these organizations should be only that of providing information and education concerning the influence of such decision, rather than making rules or prescribing whether members of the societies should or should not also be members of an engineers' union. In other words, freedom of action dictates that engineers should have the right to be union or nonunion men according to the dictates of their own consciences.

If the trend of thought in the near future indicates that engineers need more information for determining what the dictates of their consciences should be, does it not seem logical to expect that such information may be obtained effectively without the formation of any new engineering societies? Furthermore, should the results of a survey made to gather that information be such as to indicate that the engineers are not getting the recognition or compensation to which the services they render entitle them, does it not seem logical to expect that engineers are competent to find ways for having situations that seem to them unjust analyzed and corrected by peaceful methods rather than by such drastic methods as practiced by unions? One of the better methods is that used by the American Association of University Professors when a teacher reports that the college or university by which he is employed has been using unfair practice.

Indeed, engineers will delay the attainment of the high professional status so eagerly sought in direct proportion to the amount by which they deviate from the high ideals epitomized by Doctor Vannevar Bush, ${ }^{3}$ president of the Carnegie Institution and formerly vice-president and dean of Massachusetts Institute of Technology, in his address before the meeting of the American Engineering Council in January 1939, as "the heights of true professional attainment, where honor and individual recognition by fellows is the real reward, and where the watchword is that old, old theme, which has never lost its power, and which may yet save a sorry world, simple ministration to the people."

\section{REFERENCES}

1. The Engineering Profession, Gano Dunn. Electrical Engineering volume 56, October 1937, pages 1235-8.

2. Unionization of Engineers, James H. Herron. Mechanical Engineering, November 1939, volume 61 , pages $788-9$.

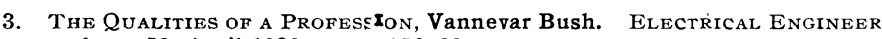
ING, volume 58, April 1939, pages 156-60. 